Link article (Style APA): Plokhikh V. V. (2021). Assessment of subject's readiness for urgent actions using the variations of sensorimotor response tasks. Insight: the psychological dimensions of society, 5, 46-6 5. DOI: 10.32999/2663-970X/2021-5-4

Link article (Style DSTU 8302: 2015): Plokhikh V. V. Assessment of subject's readiness for urgent actions using the variations of sensorimotor response tasks. Insight: the psychological dimensions of society, 2021, 5, 46-65. DOI: 10.32999/2663-970X/2021-5-4

UDC 159.93:159.937.23:159.938.3

\title{
Assessment of subject's readiness for urgent actions using the variations of sensorimotor response tasks
}

\author{
Оцінка готовності суб'єкта до термінових дій \\ з використанням варіацій завдань сенсомоторного реагування
}

Received: March 15, 2021

Accepted: May 25, 2021

\author{
Plokhikh Viktor Volodymyrovych \\ Doctor of Psychology, Professor, \\ Department of General Psychology \\ V. N. Karazin Kharkiv National University, \\ Ukraine \\ plokhikh_v@ukr.net, \\ ORCID 0000-0001-7897-3417
}

\author{
Плохіх Віктор Володимирович \\ доктор психологічних наук, професор, \\ кафедра загальної психології \\ Харківський національний університет \\ імені В. Н. Каразіна, Україна \\ plokhikh_v@ukr.net, \\ ORCID 0000-0001-7897-3417
}

\begin{abstract}
The purpose of the research is to identify the scope of combined use of different options of sensorimotor response to assess the effectiveness of the subject's reorientation from one apperception scheme to another. The empirical research has used the method of a laboratory experiment with an intra-subject implementation plan. 66 students have been the study participants. Computer hardware has been used. The study participants have performed a series of trials of a simple sensorimotor reaction, a sensorimotor reaction of choice and a double choice task, which primarily provides for immediate determination of the apperception scheme and then - selection of an action option. Results. The research has established a significant reduction of the reaction time under increasing orientation time in a double choice task for one and three alternate solutions (the Friedman test is respectively: $\chi^{2} \mathrm{r}=300,65$ ( $\mathrm{df}=5$; $\mathrm{p}<.001)$ and $\chi^{2} \mathrm{r}=62.67(\mathrm{df}=5 ; \mathrm{p}<.001)$. The author
\end{abstract}

\begin{abstract}
Анотація
Метою дослідження $\epsilon$ визначення можливостей поєднаного використання різних варіантів сенсомоторного реагування для оцінки ефективності переорієнтування суб'єкта з однієї апперцептивної схеми дій на іншу. В емпіричному дослідженні застосовано метод лабораторного експерименту з внутрішньосуб'єктним планом реалізації. Досліджуваними в експерименті були 66 студентів. Використовувалась комп'ютерна техніка. Досліджувані виконували серії спроб простої сенсомоторної реакції, сенсомоторної реакції вибору та задачі "подвійного вибору”, в якій спочатку передбачалося оперативне визначення апперцептивної схеми дій, а потім - вибір варіанту дій. Результати. Встановлено суттєве зменшення часу реакції при збільшенні часу орієнтування в задачі "подвійного вибору" для одного і для трьох варіантів рішень (критерій Фрідмана відповідно: $\chi^{2} \mathrm{r}=300,65$ (df = 5; $\mathrm{p}<.001)$ та $\chi^{2} \mathrm{r}=62.67(\mathrm{df}=5 ; \mathrm{p}<.001)$. Були отримані
\end{abstract}


Assessment of subject's readiness for urgent actions using the variations of sensorimotor response tasks

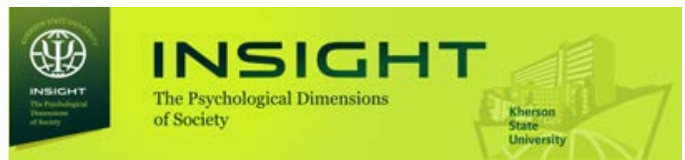

has obtained the mathematical models of the linear relationship of the time change in a sensorimotor response for a stimulus from time of orientation in the two indicated variants. The realization of the Hick' Law in the experiment has been confirmed: a simple sensorimotor reaction of the study participants is quicker than a reaction of choice between three alternatives (the Wilcoxon signed-rank test: $\mathrm{Z}=-7.073$; $\mathrm{p}<.001$ ). The identity of organizing the response processes for the variants of a double choice task has been defined. To solve a double choice task, there has been established the availability of anticipation effect for reactions to one possible variant of a stimulus under the values of the orientation time of $.25 \mathrm{sec}$ and $30 \mathrm{sec}$ (respectively: $\mathrm{t}=3.138$ as $\mathrm{p}=.003$; $\mathrm{t}=8.656$ as $\mathrm{p}<.001$ ). Conclusion. The assessment of the rate of the subject's urgent actions can be implemented with the use of a double choice task that involves an immediate choice and realizing one of two variants of sensorimotor response. Automatic variations of orientation time in a double choice task allow establishing the required duration of the urgent formation of a new operative image and a mode of actions, taking into account the set criterion - the time of a simple sensorimotor reaction.

Key words: operative image, attitude, anticipation, apperception scheme, simple sensorimotor reaction, sensorimotor choice reaction.

\section{Introduction}

The transience, complexity and variability of the processes of reality-according to which modern man must organize his activities - are steadily increasing. Under such conditions, the organization of the psychological system of activity should be flexible and dynamic. In cases of radical changes in the situation, it becomes necessary to restructure the regulatory activity of the operation image as quickly as possible. By relying on the above, human actions can meet the current and expected challenges of reality.

Problems of the organization of human actions in case of emergency significant changes of conditions were actively developed by engineering psychology research, sports psychology, and extreme psychology. The archives of aviation psychology are particularly replete with illustrative examples in this respect. The facts of erroneous actions of pilots, which led to catastrophic consequences, should be considered to be the most математичні моделі лінійного зв'язку зміни часу сенсомоторного реагування на стимул від часу орієнтування у двох означених варіантах. Підтверджено реалізацію в експерименті закону У. Хіка: проста сенсомоторна реакція досліджуваних швидше реакції вибору з трьох альтернатив (критерій знакових рангів Уілкоксона: $Z=-7.073$; $\mathrm{p}<.001)$. Було визначено ідентичність організації процесів реагування для варіантів задачі “подвійного вибору". Для рішень задачі “подвійного вибору” встановлено наявність антиципаційного ефекту у випадках реакції на один можливий варіант стимулу при значеннях часу орієнтування в .25 с та .30 с (відповідно: $\mathrm{t}=3.138$ при $\mathrm{p}=.003 ; \mathrm{t}=8.656$ при $\mathrm{p}<.001)$. Висновок. Оцінка швидкості термінових дій суб'єкта може проводитися з використанням задачі “подвійного вибору”, в якій оперативно обирається й реалізується один 3 двох варіантів сенсомоторного реагування. Автоматичні варіації часу орієнтування в задачі “подвійного вибору" з урахуванням заданого критерію - часу простої сенсомоторної реакції, дозволяють визначити необхідну тривалість термінового формування нового оперативного образу і способу дій.

Ключові слова: оперативний образ, установка, антиципація, апперцептивна схема, проста сенсомоторна реакція, сенсомоторна реакція вибору.

\section{Вступ}

Швидкоплинність, складність та мінливість процесів дійсності, згідно 3 якими повинна організовувати свою діяльність сучасна людина, неухильно збільшуються. За таких умов і організація психологічної системи діяльності повинна бути гнучкою та динамічною. У випадках радикальних змін обстановки необхідною стає якомога швидка перебудова регулюючого діяльність оперативного образу. Тільки завдяки цьому дії людини можуть відповідати поточним і очікуваним викликам дійсності.

Проблематика організації дій людини при екстренних суттєвих змінах обстановки активно розроблялася у дослідженнях з інженерної психології, в психології спорту, в екстремальній психології. Особливо багатими на показові приклади в означеному аспекті $€$ архіви авіаційної психології. І найбільш виразними тут слід вважати факти помилкових дій льотчиків, які призвели до катастрофічних 
expressive in this context (Shumilov, 2006). One of the most high-profile examples of fatal mistakes in civil aviation was the mistakes of an experienced Boeing 747 pilot in assessing the take-off situation in extreme conditions of time shortage in Los Rodeos in 1977. The crash killed more than 580 people on two planes that collided on the takeoff runway. Another example is the crash of a DC-10 near Chicago in 1979 due to the loss of an engine on takeoff and the subsequent aircraft crew's incorrect assessment of the critical situation. The pilots paid too much attention to the guidelines of the on-board computer, which failed to function, and did not realize the actual course of events up to time. The crash of the A 300310 aircraft near Mizhrichensk in 1994 is a prime example in the aspect under consideration. This crash was caused by some errors and violations on the part of the crew, which led to an unauthorized shutdown of the autopilot and a sharp change in the flight situation. The pilots failed to notice, identify and remedy the emergency in due time.

It should be added that the study of peculiarities of the formation of the flight's image and the actions of a pilot in an emergency, including the unauthorized shutdown of the autopilot, generates a specific interdisciplinary research direction. The principle of an "active operator" by V. O. Ponomarenko should be regarded as one of the important contributions in this area (Zavalova et al., 1986). It is noted that upon unexpected significant variations in the situation, the operation image regulating the subject's actions changes in content and even deteriorates in many cases. At the same time, the renewal of a full-fledged operation image takes place over a while and requires considerable mental and physical efforts.

The dynamics and variability of sports processes are not the exceptions but the rule. Athletes, more or less, but constantly must bargain for the flip of events. Moreover, they are insecure about the course and essence of possible changes. In this context, there are questions concerning the speed and adequacy of the shaping of an operation image of a situation and actions. A delay and mistakes of an athlete in assessing the situation and making relevant decisions lead to performance decline, defeats (Cheban et al., наслідків (Шумилов, 2006). Одним з найбільш гучних прикладів фатальних помилоку цивільній авіації стали помилки досвідченого пілота “Боїнга-747" в оцінці злітної ситуації в екстремальних умовах дефіциту часу в Лос-Родеосі у 1977 році. У цій катастрофі в двох літаках, що зіштовхнулися на злітній смузі, загинуло понад 580 осіб. Інший приклад - аварія літака DC-10 у 1979 році під Чикаго через втрату двигуна на злеті та наступну невірну оцінку критичної ситуації екіпажем повітряного судна. Пілоти занадто багато уваги приділили рекомендаціям бортового комп'ютера, який до того ж вийшов з ладу, і своєчасно не збагнули про реальний перебіг подій. Показовою в аспекті, що розробляється, є катастрофа літака А 300310 поряд з Міжріченськом у 1994 р. Цю катастрофу було спричинено низкою помилок та порушень з боку екіпажу, які призвели до несанкціонованого відключення автопілоту й до різкої зміни польотної ситуації. Пілоти своєчасно не змогли помітити, ідентифікувати та виправити аварійну ситуацію.

Слід додати, що вивчення особливостей формування образу польоту і дій льотчика в нештатних ситуаціях i, в тому числі, за несанкціонованого вимкнення автопілоту утворює специфічний міждисциплінарний напрямок досліджень. Одним 3 важливих напрацювань цього напрямку слід вважати i принцип "активного оператора" В. О. Пономаренко (Завалова та ін., 1986). Відзначається, що при неочікуваних суттєвих змінах ситуації оперативний образ, який регулює дії суб’єкта, змістовно змінюється, а нерідко - взагалі руйнується. При цьому відновлення повноцінного оперативного образу відбувається впродовж деякого часу і вимагає суттєвих психічних і фізичних зусиль.

Динамічність та мінливість процесів спортивної діяльності $\epsilon$ не виключенням, а правилом. Спортсмени більш або менш, але постійно, повинні бути готові до змін поточної ситуації. Але для них залишається невизначеність у напрямку та змісті можливих змін. I тут також постають питання щодо швидкості й адекватності побудови оперативного образу ситуації та дій. Несвоєчасність та помилки спортсмена в оцінці ситуації й прийнятті відповідних




2020a; Cheban et al., 2020b; Popovych et al., 2019; Van de Water et al., 2017). In some sports (for example: mountaineering, skydiving, gymnastics, diving, etc.) incorrect assessment of a situation can result in tragic consequences (Lynall et al., 2018).

The operation image, which regulates the subject's actions, is a complex multicomponent mental formation (Konopkin, 1980; Zavalova et al., 1986). This image not only reflects the peculiarities of the current situation but also takes into account the available mental and physical resources, determines the next stages of effective implementations on the way towards achieving the intended goal. The operation image is oriented in a certain way and characterized by peculiar dynamics. In this case, it can be considered as a sensory form of the manifestation of a more fundamental mental phenomenon - the actual attitude. The actual attitude functionally determines the directed readiness of the subject to accomplish certain relations with reality. In the organizational context, it is an integral entity that combines the needs and experience of an individual with information about the current situation (Chkhartishvili, 1978). The essential changes in the current situation necessitate altering the actual attitude and operation course of actions. Moreover, the previous actual attitude has inertia, stability; upon frenetic changes of the situation, it finds expression through inconsistency with changes and errors at the unconscious level of mental regulation. This feature has laid the foundation for the experimental study of the attitude.

Another important feature of the attitude is that it covers the entire duration, the development of the process the subject focuses on (Plokhikh, 2019). The integral duration of the process contains crucial features of its background and possible future. Such structural construction ensures anticipatory effects in the implementation of the operation image controlling actions (Nosov et al., 2020; Popovych et al., 2020; Zavalova et al., 1986).

In terms of a specific activity performed by a particular person, the changes in the current attitude and operation image depend on the specificity of the situation, personal рішень призводять до зниження результатів, до поразок (Cheban et al., 2020a; Cheban et al., 2020b; Popovych et al., 2019; Van de Water et al., 2017). А в деяких видах спорту (наприклад: альпінізм, парашутизм, гімнастика, дайвінг та ін.) невірна оцінка ситуації може мати й трагічні наслідки (Lynall et al., 2018).

Оперативний образ, що регулює дії суб'єкта, $\epsilon$ складним багатокомпонентним психічним утворенням (Конопкин, 1980; Завалова та ін., 1986). Цей образ не тільки відображає особливості поточної ситуації, а й враховує наявні психічні та фізичні ресурси, визначає послідовні етапи дієвих реалізацій на шляху до досягнення наміченої мети. Оперативний образ певним чином зорієнтований та характеризується своєрідною динамікою. У такому варіанті він може розглядатися як чуттєва форма прояву більш фундаментального психічного явища - актуальної установки. Актуальна установка функціонально визначає спрямовану готовність суб'єкта до реалізації певних відношень з дійсністю. Організаційно ж вона $є$ інтегральним утворенням, яке поєднує потреби й досвід особистості з інформацією про поточну ситуацію (Чхартишвили, 1978). Суттєві зміни поточної ситуації роблять необхідними й зміни актуальної установки та оперативного образу дій. При цьому попередня актуальна установка має певну інерційність, стійкість, і при різких змінах обстановки вона проявляється з неусвідомлюваного рівня психічної регуляції невідповідністю змінам та помилками. Саме означену особливість й було покладено в основу експериментального вивчення установки.

Ще однією важливою особливістю установки $\epsilon$ те, що вона охоплює цілісну тривалість, розгортання процесу, на якому акцентовано увагу суб'єкта (Плохіх, 2019). Цілісна тривалість процесу вміщує значущі особливості його минулого, теперішнього та можливого майбутнього. Така структурна побудова й забезпечує антиципаційні ефекти в реалізації керуючого діями оперативного образу (Nosov et al., 2020; Popovych et al., 2020; Завалова та ін., 1986).

У конкретній діяльності, яку виконує конкретна людина, зміни актуальної установки 
motivation and experience (Cheban et al., 2020s; Okubo et al., 2017; Sant'Ana et al., 2016). However, first of all, it essential that the mental mechanisms, ensuring the very change of the subject's orientation, "respond" adequately. The research of the organization of such mechanisms is not concealed - it is possible upon the condition of reducing the impact of features of the subjective experience and the current circumstances on their functioning. In the context of such a simplified model version, the possibilities of urgent structural changes of the mental organization for a pivot to a new situation come to the fore. The well-studied resources of sensorimotor response may come in useful to create an appropriate model task (Reigal et al., 2019; Silverman, 2010).

In the structure of sensorimotor reaction, one distinguishes a fundamental perceptual component focused on the signals of the relevant sensation modality. This component is a kind of expression of the current attitude and a crucial element of the operation image. The perceptual component of the sensorimotor response is substantively simplified and is based on an apperception scheme with limited content of minor elements of the experience and the current situation. The apperception scheme itself determines emphases in the information perception and its orientation in the appropriate direction of motor realization. With the increase of input signal variants and response variants, apperception schemes with the relevant response ways become more complicated. The latter relates to the psychological basis of Hick's Law, which summarizes the following correlation: with the increasing number of possible variants of the input signal, the subject's response time increases (Chuprikova, 1995). Thus, every apperception scheme differs in the rate of sensorimotor reactions for a particular number of stimulation options. By relying on the beforementioned, it should be noted that the rate of change of operation images in the sensorimotor response is largely determined by the duration of switching the psychological system of action regulation from one apperception scheme to another. Such switching can be detected by increasing or decreasing a period of the reaction time.

The purpose of the research is to identify the potential of combined use of a simple й оперативного образу залежать від багатьох особливостей ситуації, особистісної мотивації та досвіду (Cheban et al., 2020c; Okubo et al., 2017; Sant'Ana et al., 2016). Однак при цьому насамперед важливим $\epsilon$ те, щоб необхідним чином “спрацьовували” психічні механізми, які забезпечують саму зміну спрямованості суб'єкта. Дослідження організації таких механізмів не маскується і можливе за умов зменшення впливу на їх функціонування особливостей суб'єктивного досвіду та перебігу поточних обставин. У такому спрощеному модельному варіанті на передній план вже виступають саме можливості термінових структурних змін психічної організації для переорієнтації на нову ситуацію. Для створення відповідної модельної задачі можуть стати у нагоді достатньо вивчені ресурси сенсомоторного реагування (Reigal et al., 2019; Silverman, 2010).

У структурі сенсомоторної реакції виокремлюється вагомий перцептивний компонент, який зорієнтовано на сигнали відповідної модальності відчуття. Означений компонент власне і є своєрідним виразом актуальної установки й ключовою складовою оперативного образу. Перцептивний компонент сенсомоторної реакції суттєво спрощений і має в основі апперцептивну схему 3 обмеженим наповненням малозначущими елементами досвіду і поточної ситуації. Апперцептивна схема саме і визначає акценти у сприйнятті інформації та її спрямуванні у відповідному напрямку рухової реалізації. Зі збільшенням варіантів вхідних сигналів і варіантів реагування ускладнюються й апперцептивні схеми з відповідними способами реагування. Останнє саме і стосується психологічного підгрунтя закону У. Хіка, в якому узагальнюється наступне відношення: зі збільшенням кількості можливих варіантів вхідного сигналу збільшується час реагування суб'єкта (Чупрікова, 1995). Тобто кожна апперцептивна схема для певної кількості варіантів стимуляції відрізняється відповідною швидкістю сенсомоторних реакцій. Виходячи з останнього, слід відзначити, що швидкість змін оперативних образів у сенсомоторному реагуванні значною мірою визначається тривалістю переключення психологічної системи регуляції дій

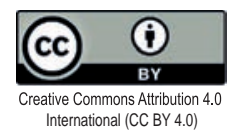


sensorimotor reaction and sensorimotor choice reaction within one task to assess the effectiveness of the subject's reorientation from one apperception scheme of response (action) to another.

Research tasks:

1. Theoretical substantiation of the potential for using a simple sensorimotor reaction and sensorimotor choice reaction within one task to assess the subject's readiness for the urgent changes of the operation image and mode of actions.

2. To establish the empiric effectiveness of using "double-choice" tasks with automatic variations of orientation time to assess the subject's capacity towards an urgent formation of a new operation image and mode of actions.

\section{Materials and methods}

Study participants were represented by 66 male and female students (age: $M e=20, \min =17$, $\max =25$ ). The intra-subject experimental design was realized under the framework of the research. The study involved computer hardware.

According to the experimental design, the study participants carried out a series of tasks, including sensorimotor actions in various conditions. The experimental tasks were realized in the form of a computer program based on the relevant algorithm. When completing tasks, the study participants had to respond to the appearance of a stimulus on-screen as quickly as possible (aburgundy square) by pressing the corresponding keyboard. Differentexperimentaltasks determined the relevant number of variants of the stimuli and a place of the appearance of a concrete stimulus on the screen in the subsequent trial through a random number generator. The study participants made training trials before a series of valid ones. The time interval between trials varied randomly within $1.70 \div 2.30 \mathrm{sec}$.

In series 1 , the study participants completed a task which was organized upon the scheme of a simple sensorimotor reaction. According to the scheme, a stimulus-square automatically appeared in the middle of the monitor screen. In response to the appearance of the stimulus, a study participant had to press the key " $\downarrow$ " as quickly as possible. The reaction time was з одної апперцептивної схеми на іншу. I таке переключення може бути діагностовано через збільшення або зменшення часу реакції.

Мета дослідження - визначення можливостей поєднаного використання в одній задачі простої сенсомоторної реакції та сенсомоторної реакції вибору для оцінки ефективності переорієнтування суб'єкта з однієї апперцептивної схеми реагування (дій) на іншу.

Завдання дослідження:

1. Теоретично обгрунтувати можливості використання простої сенсомоторної реакції та сенсомоторної реакції вибору для оцінки готовності суб'єкта до термінових змін оперативного образу та способу дій.

2. Емпірично встановити ефективність використання задачі "подвійного вибору" 3 автоматичними варіаціями часу орієнтування для оцінки можливостей суб'єкта щодо термінового формування нового оперативного образу і способу дій.

\section{Матеріали та методи}

У якості досліджуваних виступили 66 студентів чоловічої та жіночої статі (вік: $M e=20$, $\min =17, \max =25)$.У дослідженні було реалізовано внутрішньосуб'єктний експериментальний план. Робота проводилася з використанням комп'ютерного обладнання.

За експериментальним планом досліджувані виконали низку серій завдань 3 виконанням сенсомоторних дій в різних умовах. Експериментальні завдання було реалізовано у вигляді комп'ютерної програми за розробленим відповідним алгоритмом. При вирішенні завдань досліджуваним слід було як найшвидше реагувати на появу на екрані монітору стимулу (квадрату бордового кольору) шляхом натискання відповідної клавіші клавіатури. У різних експериментальних завданнях актуальна безліч варіантів стимулів і місце появи конкретного стимулу на екрані в наступній спробі визначалося за допомогою датчика випадкових чисел. Досліджувані перед серіями залікових спроб виконували тренувальні спроби. Інтервал часу між спробами змінювався випадково в межах $1.70 \div 2.30$ с.

У серії 1 досліджуваними вирішувалося завдання, яке було організоване за схемою 


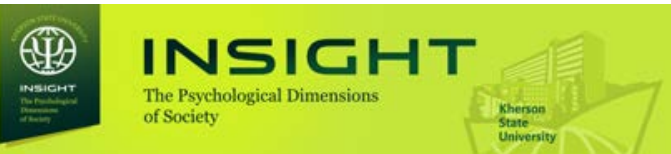

fixed. In this series, the study participants made $5-7$ training and 25 valid trials following the next instruction: "You should respond to the appearance of a burgundy square in the middle of the screen as quickly as possible by pressing the key " $\downarrow$ ”.

In series 2, the study participants performed a task which was based the scheme of sensorimotor choice response. In this task, the stimulus-square appeared in the middle of the screen (horizontal coordinate) in one of three possible spots: to the left of the center of the screen; in the center of the screen; to the right of the center of the screen. For each option of stimulus appearance, a study participant was suggested responding as quickly as possible

\section{Plokhikh Viktor}

простої сенсорномоторної реакції. Згідно 3 такою схемою у центрі екрану монітора автоматично з'являвся стимул-квадрат. У відповідь на появу стимулу досліджуваний повинен був якнайшвидше натиснути на клавіатурі на клавішу - “ $\downarrow$ ”. Визначався час реагування. У цій серії досліджувані виконували 5-7 тренувальних і 25 залікових спроб, дотримуючись наступної інструкції: «Вам слід якнайшвидше реагувати на появу в центральній частині екрану бордового квадрату шляхом натискання клавіші - “Џ”».

У серії 2 досліджувані виконували завдання, організоване за схемою сенсорномоторної

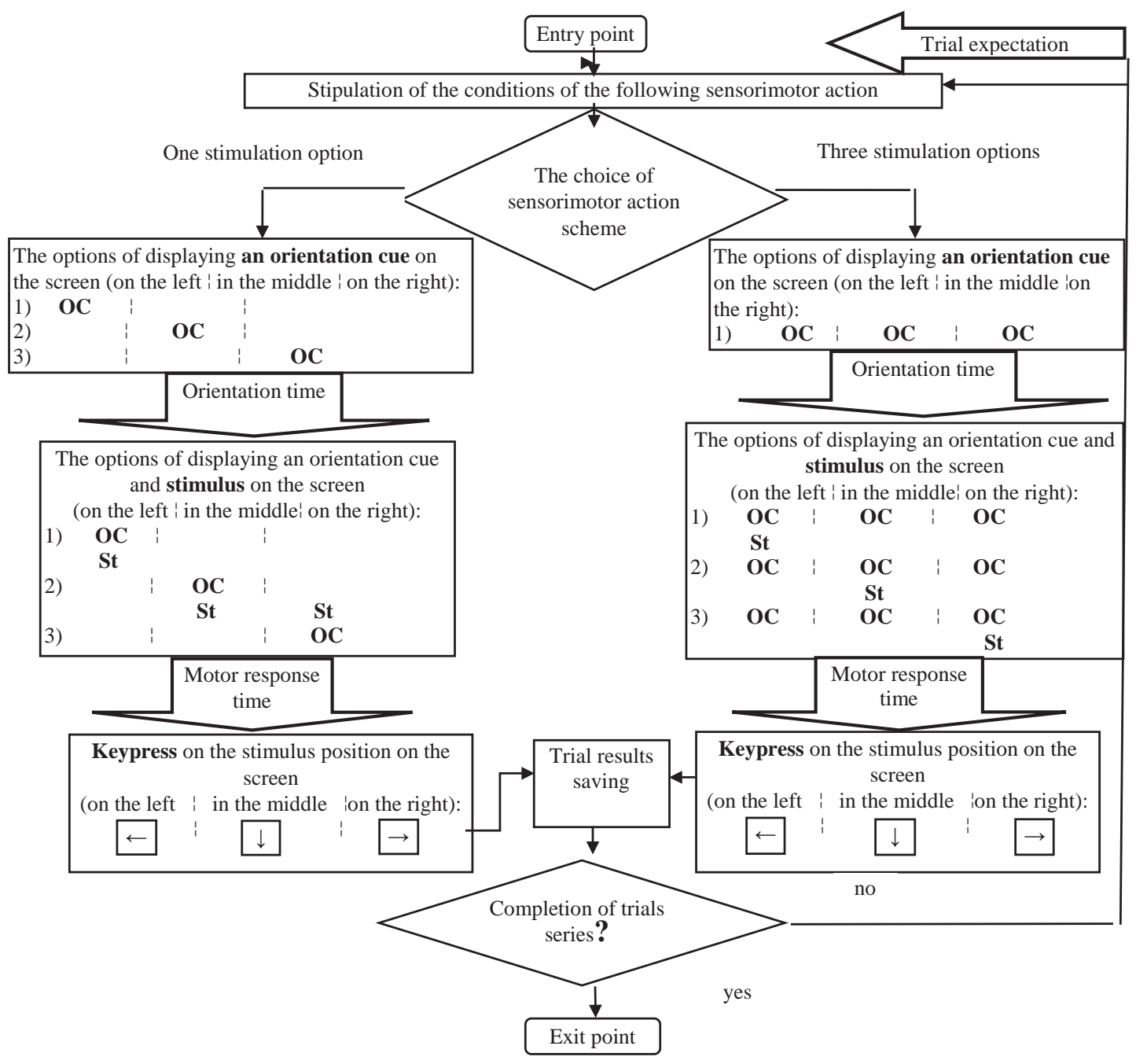

Fig. 1. The scheme of the organization of sensorimotor actions in a double choice task, where OC - an orientation cue; St - a stimulus. 
by pressing the following keys: the stimulus is on the left - " $\leftarrow$ "; the stimulus is in the middle - " $\downarrow$ "; the stimulus is on the right - " $\rightarrow$ ". The response speed of a study participant was measured automatically. Series 2 consisted of $5-7$ training and 25 valid trials. Regarding the task in series 2, a study participant had the following instruction: "You should respond to the appearance of a burgundy square in one of the possible spots on the monitor screen as quickly and correctly as possible by pressing the relevant keyboard key (the keys are next to each other): the square is on the screen to the left of center $-\leftarrow$ "; the square isin the middle of the screen- " $l$ "; the square in on the screen to the right of the center " $\rightarrow$ ". реакції вибору. У цьому завданні стимул-квадрат з'являвся в середній частині екрану (горизонтальна координата) на одномуз трьох можливих місць: зліва від центру екрану; у центрі екрану; справа від центру екрану. На кожний варіант появи стимулу досліджуваному пропонувалося якнайшвидше реагувати натисканням на клавіатурі наступних відповідних клавіш: стимул зліва - клавіша “ $\leftarrow$; стимул у центрі - клавіша “ل”; стимул справа клавіша “ $\rightarrow$ ". Автоматично визначалася швидкість реагування досліджуваного. В серії 2 виконувалося 5-7 тренувальних і 25 залікових спроб. Стосовно виконання завдання

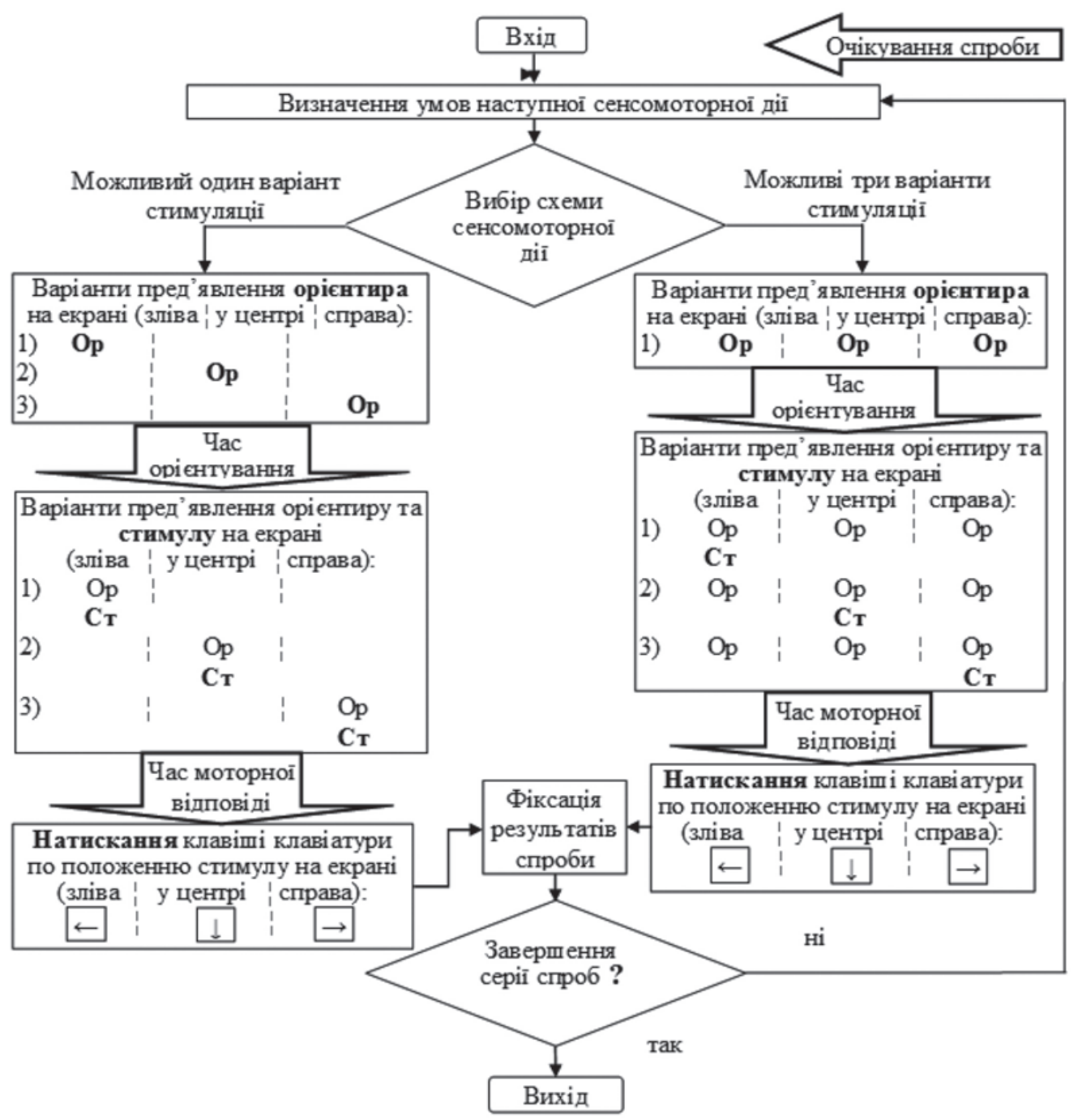

Рис. 1. Схема організації сенсомоторних дій у завданні “подвійного вибору", де: Оp - орієнтир; Ст - стимул. 
In series 3, 4 and 5, the study participants completed double choice tasks (DC). At the first stage of the task, one had to decide upon the scheme of the following actions: including one option of stimulation (1_PS) or three options of stimulation (3_PS). At the second stage of task completion, one pressed the relevant key of the moveable answer (fig. 1). The 1_PS option was realized on the screen as one of three possible alternatives of the 3_PS realization.

ADC task was developed by following a response scheme with a cue and given the effects meeting Hick's Law (Chuprikova, 1995). When elaborating the experimental problem, the author kept in mind that in uncertain environment, the subject focuses on the most extensive information context and the largest scope number of possible options for situation development (Konopkin, 1980). Moreover, it should be added that the required narrowing of the context and focusing on the significant point take some time.

In each subsequent trial of the DC task, the options of a place of presentation were shown on the screen at some time (orientation time) before displaying a stimulus. Thus, burgundy circles were rendered above the possible spots where the stimulus could appear (see Fig. 1). If the 1_PS scheme was offered, one cue circle was depicted above the place (on the screen: on the left; in the middle; on the right) where the stimulus was subsequently appeared. In case of the 3_PS scheme, cue circles were reflected over all three possible spots of stimulus appearance. Then, the stimulus appeared in one of three indicated spots. Both according to the 1_PS scheme and 3_PS scheme, in response to the stimulus, the study participant had to press the key that corresponds to the stimulus position on the screen as quickly as possible (see Figure 1). In the DC task, the keyboard keys and spots of displaying stimuli on the screen correlated in the same manner as in a choice reaction task in series 2. The instruction for the DC task was as follows: "Before the appearance of the stimulussquare, the spots of its possible appearance (one or three) are indicated on the screen by displaying small burgundy circles over them. You should respond as quickly and correctly as possible to the appearance of a burgundy stimulus-square у серії 2 досліджуваному надавалася наступна інструкція: «Вам необхідно якомога швидше i правильно реагувати на появу бордового квадрату в одному з можливих місць на екрані монітору шляхом натискання відповідної клавіші клавіатури (клавіші знаходяться поряд): квадрат на екрані зліва від центру - “є”; квадрат в центрі екрану - “ل”; квадрат на екрані справа від центру - “ $\rightarrow$ ”.

У серіях 3, 4 та 5 досліджувані виконували завдання “подвійного вибору" (ПДВ). В цьому завданні на першому етапі треба було визначитись зі схемою наступних дій: з одним варіантом стимуляції (1_MC) або з трьома варіантами стимуляції (3_MC). На другому етапі вирішення завдання натискалася відповідна клавіша в руховій відповіді (рис. 1). Варіант 1_МС було реалізовано на екрані як один з трьох можливих випадків реалізації варіанту 3_MC.

Задача ПДВ розроблялася за схемою реагування $з$ попереджаючим сигналом та з врахуванням ефектів, що відповідають закону У. Хіка (Чупрікова, 1995). У побудові експериментальної задачі враховувалося, що в умовах невизначеності суб'єкт орієнтується на найбільш широкий інформаційний контекст та на найбільшу кількість можливих варіантів розвитку ситуації (Konopkin, 1980). До цього ж слід додати, що необхідне звуження контексту і зосередження уваги на актуально важливому вимагає деякого часу.

У кожній наступній спробі в задачі ПДВ за деякий час (час орієнтування) до пред'явлення стимулу на екрані вказувалися можливі варіанти місця пред'явлення. Для цього над можливими місцями, де може потім з'явитися стимул, відображувалися кола-орієнтири бордового кольору (див. рис. 1). Якщо пропонувалася схема 1_MC, то відображувалося одне коло-орієнтир саме над тим місцем (на екрані: зліва; у центрі; справа), де потім пред'являвся сам стимул. У випадку схеми 3_MC кола-орієнтири відображувалися над усіма трьома можливими місцями появи стимулу. Стимул потім пред'являвся в одному з трьох вказаних місць. I по схемі 1_MC, і по схемі 3_MC у відповідь на пред'явлення стимулу досліджуваний повинен якомога швидше натискати ту клавішу клавіатури, яка відповідала положенню стимулу на 
Assessment of subject's readiness for urgent actions using the variations of sensorimotor response tasks

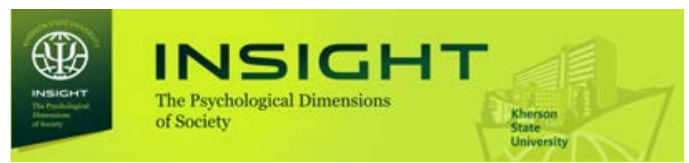

on the screen by pressing the appropriate key in the following correlations: the square is on the left of the screen - " $\leftarrow$ "; the square is in the middle of the screen - " $\downarrow$ "; the square is on the right of the screen - " $\rightarrow$ "”.

The method of changing the orientation time differed in the experimental series stipulating task performance according the DC scheme. In series 3 and 4 , there were three possible values of the orientation time, one of which was chosen for the subsequent trial using the random number generator. Series 3 contained the following options of the orientation time: $05 \mathrm{sec}$; $15 \mathrm{sec}$; $.25 \mathrm{sec}$. In series 4 , the possible orientation time was as follows: $.10 \mathrm{sec}$; $20 \mathrm{sec} ; .30 \mathrm{sec}$. In series 5 , the orientation time automatically changed for $.05 \mathrm{sec}$ (but not less than zero seconds). The outcome of the software comparison of the motor response time in the previous trial (only for 1_PS) with the criterion value was a signal of changing orientation time for each subsequent one. The median value of a simple sensorimotor response, which had been preliminarily entered in the software settings of the DC task, was set in series 1 . If the execution time of the previous trial exceeded the criterion, orientation time for the next trial was increased by $.05 \mathrm{sec}$; if, conversely - orientation time for the next trial was reduced by $.05 \mathrm{sec}$.

In series 3 and 4 , it was necessary to perform 7-10 training and 65 valid trials when performing the DC task.

In the experimental DC task, influence factors and respectively independent variables involved orientation time; apperception schemes for response in 1_PS or 3_PS. The time of a motor response to the appearance of the stimulus-square was a dependent variable in all cases. On the one hand, orientation time in the relevant situation determined the transition from the apperception scheme in the 3_PS option to the apperception scheme in the 1_PS option. On the other hand, the cue could initiate the anticipation process. The influence factors had to act as a cohesive whole: the cue both pointed at the actual apperception scheme and "started" the countdown of orientation time before the appearance of the stimulus square.

After each trial, the data array fixed the following information: stimulus code; an interval between the trials; sensorimotor reaction екрані (див. рис. 1). Клавіші клавіатури й місця пред'явлення стимулів на екрані в задачі ПДВ співвідносилися так саме, як і в задачі реакції вибору в серії 2. Інструкція щодо виконання задачі ПДВ була наступною: «За деякий час до появи стимула-квадрата на екрані вказуються місця його можливою появи (одне або три) через відображення над цими місцями малих кіл бордового кольору. Ви повинні якомога швидше та правильно реагувати на появу бордового стимулу-квадрату на екрані натисканням відповідної клавіші у таких співвідношеннях: квадрат на екрані зліва - “є”; квадрат у центрі екрану - “ل”; квадрат на екрані справа - " $\rightarrow$ "».

В експериментальних серіях 3 виконанням завдань по схемі ПДВ відрізнявся спосіб зміни часу орієнтування. В серіях 3 та 4 було по три можливих значення часу орієнтування, одне з яких обиралося для чергової спроби за допомогою датчика випадкових чисел. У серії 3 варіанти часу орієнтування були наступні: .05 c; .15 c; .25 с. У серії 4 можливий час орієнтування був: 10 c; .20 c; .30 с. У серії 5 час орієнтуванні від спроби до спроби автоматично змінювався на .05 с (але не менше нуля секунд). Показанням до змін часу орієнтування для кожної наступної спроби був результат програмного порівняння часу рухової відповіді у виконаній попередній спробі (тільки для варіанту 1_MC) із значенням критерію. Критерієм для зміни часу орієнтування було заздалегідь занесене до програмних установок задачі ПДВ встановлене в серії 1 значення медіани простої сенсомоторної реакції. Якщо час виконання попередньої спроби був більше критерію, то час орієнтування для наступної спроби збільшувався на .05 с; якщо навпаки час орієнтування для наступної спроби зменшувався на .05 с.

У серіях 3 та 4 при виконанні задачі ПДВ необхідно було виконувати по 7-10 тренувальних і по 65 залікових спроб. У серії 5 досліджувані виконували 7-10 тренувальних і 41 залікову спробу.

В експериментальній задачі ПДВ факторами впливу і відповідно незалежними змінними були: час орієнтування; апперцептивні схеми для реагування у варіантах 1_MC або 
time; the fact of correct selection of the key for the motor response; orientation time for the DC task; current apperception scheme (1_PS or 3_PS) for the DC task. After completing a series of trials, the data array was programmatically processed, and the findings were converted into the results file of a study participant. The success rate of the study participant was assessed according to the following parameters: sensorimotor reaction time; orientation time, operations accuracy. The study data were processed by the statistical package IBM SPSS Statistics 20.

\section{Results}

The author ran a check of the distribution of samples of empirical data of the study group for compliance with the normal law (the KolmogorovSmirnov test). Such calculations showed a positive outcome in most cases. However, the normal law was not established in data distributions of the samples with simple reaction time (series 1 ) and choice reaction (series 2). In the study group, statistical indicators of "reaction time" for completing the DC task in series 3 and 4 were combined in table 1.

By using the Friedman test $\left(\chi^{2} r\right.$-), the statistical analysis of the significance of MTR changes upon shifting the orientation time in the DC task for 1 PS and 3PS was conducted in the context of combined statistics of series 3 and 4 (see table 1). The following significant results were obtained: 1_PS - $\chi^{2} r=300,65(d f=5 ; p<.001) ; 3$ _ PS $\chi^{2} r=62.67(d f=5 ; p<.001)$.

The results in table 1 indicate the inverse dependence of the motor reaction time on the orientation time. Taking into account the above, mathematical models of the linear relationship of changes in the mean values of the time of sensorimotor response to the stimulus derived from the orientation time were obtained in two versions of the accomplishment of the DC task (table 2). According to these models, one can mark a unique correspondence of orientation time with reaction time in the DC task when reorienting psychological mechanisms from three expected options of stimulations to one. At the same time, such a re-reorientation took place upon orientation time value of $.05 \sec (t=3.207$; $\mathrm{p}=.002$ ).
3_MC. Залежна змінна у всіх випадках - час рухової відповіді на появу стимулу-квадрату. Час орієнтування, з одного боку, при відповідній ситуації зумовлював перехід 3 апперцептивної схеми у варіанті 3_MC на апперцептивну схему у варіанті 1_MC. 3 іншого боку, попереджувальний сигнал міг бути ініціацією процесу антиципації. Фактори впливу мали діяти комплексно: орієнтувальний сигнал і вказував на актуальну апперцептивну схему, i "запускав" відлік часу орієнтування до появи стимулу-квадрату.

Після кожної спроби у масиві даних фіксувалася наступна інформація: код стимулу; час поміж спробами; час сенсомоторного реагування; факт правильності вибору клавіші для рухової відповіді; час орієнтування для задачі ПДВ; поточна апперцептивна схема (1_MC або 3_MC) для задачі ПДВ. Після завершення серії спроб масив даних програмно оброблявся і результати переводилися у файл результатів досліджуваного. Успішність дій досліджуваного оцінювалася за наступними параметрами: час сенсомоторної реакції; час орієнтування, правильність дій. Обробка даних дослідження проводилася за допомогою статистичного пакету IBM SPSS Statistics 20.

\section{Результати}

Проводилася перевірка розподілів вибірок емпіричних даних групи досліджуваних на відповідність нормальному закону (критерій Колмогорова-Смирнова). У таких розрахунках було отримано стверджуючий результат у більшості варіантів. Однак для розподілів даних у вибірках з часом простої реакції (серія 1) та реакції вибору (серія 2) нормальний закон не був встановлений. Статистичні показники «час реакції» у групі досліджуваних для рішень задачі ПДВ в серіях 3 та 4 поєднано представлені в табл. 1.

3 використанням $\chi^{2} r$-критерію Фрідмана проводився статистичний аналіз значущості змін часу реакції при зміні часу орієнтування в задачі ПДВ для випадків 1_MC та 3_MC по поєднаним статистикам серій 3 та 4 (див. табл. 1). Були отримані наступні значущі результати: 1_MC $-\chi^{2} r=300,65(d f=5 ; p<.001)$; $3 \_\mathrm{MC}-\chi^{2} r=62.67(d f=5 ; p<.001)$.

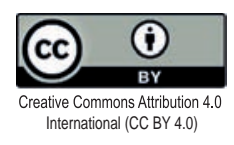


Assessment of subject's readiness for urgent actions using the variations of sensorimotor response tasks

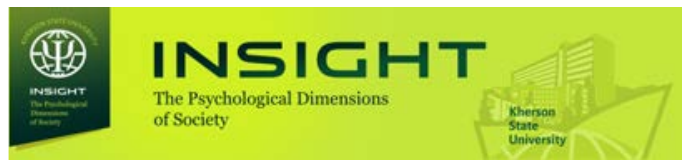

Результати в табл. 1 свідчать про зворотну залежність часу моторної відповіді від часу орієнтування. 3 урахуванням цього були отримані математичні моделі лінійного зв'язку змін середніх значень часу сенсомоторного реагування на стимул від часу орієнтування у двох варіантах реалізації задачі ПДВ (табл. 2). Згідно з цими моделями можна стверджувати однозначну відповідність часу орієнтування і часу реакції в задачі ПДВ при переорієнтуванні психологічних механізмів з трьох очікуваних варіантів стимуляції на один. При цьому таке переорієнтування відбувається вже при значенні часу орієнтування в .05 с. $(\mathrm{t}=3.207$; $\mathrm{p}=.002)$.

3 використанням критерію знакових рангів Уілкоксона визначалася статистична різниця

Table 1. Motor reaction time in the experimental study group $(n=66)$ in series 3 and 4 in the case of different values of orientation time in the DC task

Таблиця 1. Час рухової відповіді у групі досліджуваних (n=66) у серіях 3 та 4 експерименту у разі різних значень часу орієнтування в задачі ПДВ

\begin{tabular}{|c|c|c|c|c|c|c|c|}
\hline \multirow{2}{*}{$\begin{array}{l}\text { The number of stimuli } \\
\text { options } \\
\text { Кількість варіантів } \\
\text { стимуляції }\end{array}$} & \multirow{2}{*}{$\begin{array}{l}\text { Parameter, c } \\
\text { Параметр, с }\end{array}$} & \multicolumn{6}{|c|}{$\begin{array}{l}\text { Orientation time } \\
\text { Час орієнтування }\end{array}$} \\
\hline & & .050 & .100 & .150 & .200 & .250 & .300 \\
\hline \multirow{3}{*}{1} & $\bar{M}$ & .336 & .299 & .270 & .227 & .194 & .144 \\
\hline & $M e$ & .335 & .300 & .270 & .230 & .210 & .140 \\
\hline & $S D$ & .044 & .040 & .046 & .051 & .063 & .069 \\
\hline \multirow{3}{*}{3} & $\bar{M}$ & .321 & .313 & .301 & .294 & .290 & .287 \\
\hline & $M e$ & .320 & .310 & .300 & .290 & .290 & .280 \\
\hline & $S D$ & .039 & .035 & .039 & .039 & .040 & .037 \\
\hline
\end{tabular}

Table 2. Parameters of mathematical models of the linear dependence of sensorimotor reaction time of the studied group on the cue in the options involving one and three possible stimuli derived from the orientation time in the DC task in the 3 and 4 experimental series $(d f=4)$

Таблиця 2. Параметри математичних моделей лінійної залежності часу сенсомоторного реагування досліджуваних групи на сигнал у варіантах з одним та трьома можливими стимулами від часу орієнтування в задачі ПДВ у серіях 3 и 4 експерименту $(d f=4)$

\begin{tabular}{|c|c|c|c|c|}
\hline \multirow{2}{*}{$\begin{array}{c}\text { The number of stimulation options } \\
\text { Кількість варіантів стимуляції }\end{array}$} & \multicolumn{2}{|c|}{$\begin{array}{c}\text { Model раaаmeters } \\
\text { Параметри моделі }\end{array}$} & \multicolumn{2}{c|}{$\begin{array}{c}\text { Сharacteristics } \\
\text { Характеристики }\end{array}$} \\
\cline { 2 - 5 } & $\begin{array}{c}\text { Constant } \\
\text { Константа }\end{array}$ & $\begin{array}{c}\text { Соеfficient } \\
\text { Коефіцієнт }\end{array}$ & $\boldsymbol{R}^{\mathbf{2}}$ & $\boldsymbol{p}$ \\
\hline 1 & .376 & -.751 & .995 & .000 \\
\hline 3 & .326 & -.141 & .952 & .001 \\
\hline
\end{tabular}

Notes: $\mathrm{p}$ - the probability of making a type I error; $\mathrm{R}^{2}$ - the proportion of the dispersion of motor actions time stimulated by the orientation time.

Примітка: $\mathrm{p}$ - імовірність похибки 1 роду; $\mathrm{R}^{2}$ - доля дисперсії часу рухових дій, обумовлена часом орієнтування.

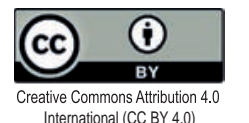


cue that is unstable in time. It means that in this case, values of the simple reaction and the choice reaction adjusted by anticipatory effects should act as a kind of conditional constraints according to which the reactions of a study participant should be actualized depending on the current orientation time. To prove the above, the difference in the motor response time in the study of 1_PS and 3_PS in series 5 in the DC task was established (Table 3$)$. It showed the result ( $\mathrm{Z}=$ -7.081; $\mathrm{p}$ <.001), which by the nature of the ratio, corresponds to the outcome of a preliminary comparison of the response rate in series 1 and 2 . The established fact of the availability of a range of values for the time of change of the apperception scheme of sensorimotor action also confirms the implementation of Hick's Law in the DC task both in series 3 and 4 and in series 5 (see tables 1 and 3 ).

Inthecontextoftheresultspresented,tworelated aspects of the consideration of the organization of sensorimotor actions in the DC task are separated. First, it is the fixation of the minimum time, according to the mathematical model (see table 2), required for the full reorientation of the subject to the apperception response scheme in the 1_PS option and establishing its compliance with the empirical result. Second, it is the establishment of the identity of the structure of sensorimotor response to different task options in the case of variable and fixed values of orientation time. між часом виконання досліджуваними простої сенсомоторної реакції і часом реакції вибору (табл. 3). Було підтверджено, що проста сенсомоторна реакція досліджуваних в експерименті швидше реакції вибору з трьох альтернатив $(Z=-7.073 ; p<.001)$.

Лінійний зв'язок зменшення часу сенсомоторної реакції на стимул у варіанті 1_MC в задачі ПДВ при збільшенні часу орієнтування $€$ суттєво обмеженим. При великих значеннях часу орієнтування, що наближаються до величин міжстимульного інтервалу, задача ПДВ за своєю апперцептивною схемою перетворюється на задачу простого реагування або на задачу реакції вибору, але з наявним нестабільним у часі попереднім орієнтиром. Тобто, скореговані антиципаційними ефектами значення простої реакції та реакції вибору у такому випадку повинні виступати в якості своєрідних умовних обмежень, відповідно до яких, в залежності від поточного часу орієнтування, й повинні реалізовуватися реакції досліджуваного. Для підтвердження цього встановлювалася різниця між часом рухової відповіді у групі досліджуваних у варіантах 1_MC та 3_MC в серії 5 в задачі ПДВ (табл. 3). Було отримано результат $(Z=-7.081 ; p<.001)$, що за характером співвідношення відповідає результату попереднього порівняння швидкості реагування в серіях 1 і 2 . Доведений факт наявності діапазону значень для часу зміни апперцептивної схеми сенсомоторної дії також

Table 3. Statistical values of sensorimotor response time in the tasks involving a simple sensorimotor reaction (series 1), choice reaction (series 2), double choice upon one or three variants of stimulation (series 5) Таблиця 3. Статистичні показники часу сенсомоторного реагування в задачах на просту сенсомоторну реакцію (серія 1), реакцію вибору (серія 2), “подвійного вибору” при одному або при трьох варіантах стимуляції (серія 5)

\begin{tabular}{|c|c|c|c|c|}
\hline \multirow{2}{*}{$\begin{array}{c}\text { Statistical } \\
\text { parameter } \\
\text { Статистичний } \\
\text { параметр }\end{array}$} & \multirow{2}{*}{$\begin{array}{c}\text { Series } 1 \\
\text { (one-alternative } \\
\text { stimulus) } \\
\text { Серія } 1 \text { (один } \\
\text { варіант стимулів) }\end{array}$} & \multirow{2}{*}{$\begin{array}{c}\text { Series } 2 \\
\text { (three-alternative } \\
\text { stimuli) } \\
\text { Серія } 2 \text { (три } \\
\text { варіанти стимулів) }\end{array}$} & \multicolumn{2}{|c|}{$\begin{array}{c}\text { Series } 5 \\
\text { Серія } 5\end{array}$} \\
\hline & & & $\begin{array}{c}\text { one-alternative } \\
\text { stimulus } \\
\text { один варіант } \\
\text { стимулів } \\
\end{array}$ & $\begin{array}{c}\text { three-alternative } \\
\text { stimuli } \\
\text { три варіанти } \\
\text { стимулів } \\
\end{array}$ \\
\hline $\bar{M}, \mathrm{c}$ & - & - & .225 & .304 \\
\hline$S D, \mathrm{c}$ & - & - & .028 & .029 \\
\hline$M e, \mathrm{c}$ & .220 & .330 & .230 & .305 \\
\hline $\min$ & .150 & .260 & .150 & .210 \\
\hline $\max$ & .280 & .420 & .280 & .370 \\
\hline
\end{tabular}


Empirically, the minimum required orientation time for the full implementation of the 1_PS option in series 5 ( $=.195 \mathrm{sec}$; $\mathrm{SD}=.062 \mathrm{sec})$ was established. Using a mathematical model for the 1_PS option, the required orientation time was calculated with the application of the median of the simple reaction time in series 1 to the formula (see Table 3). A value of .208 sec was obtained. The estimated required reorientation time turned out to be statistically a little different from the above empirical value of the minimum required orientation time (one-sample t-test: $t=1.762 ; p=.083$ ). Therefore, a criterion value used in the series sufficiently coincides both in the theoretical model and the practical implementation of series 5 when the time of the simple sensorimotor reaction from series 1 is set as a criterion for the program variable of orientation time. In addition, the value of the response time for 1_PS in series 5 does not significantly differ from the criterion value of the median of a simple sensorimotor response in series 1 (one-sample t-test: $t=1.354 ; p=.181$ ).

The identity of the organization of response processes in the variants of the DC task with fixed values of orientation time (series 3 and 4) and a variable value of orientation time (series 5) was established. In order to do that, the author, based on the mathematical models (see table 2), calculated theoretical determinations of the required orientation time and the corresponding sensorimotor action time for 1_PS and 3_PS, which were subsequently compared (one-sample t-test) with the relevant empirical data in series 5. Several calculations were made. To confirm the correspondence of mathematical models of the dependence of sensorimotor response time on orientation time for series 5 in 1_PS and 3_PS, theoretical values of sensorimotor response time were calculated when substituting the empirical value of the required orientation time in series 5 (calculated: for 1_PS - 230 sec; for 3_PS $.299 \mathrm{sec}$ ). The calculated theoretical values were statistically compared with the empirical results in series 5 . There were no significant statistical differences in theoretical and empirical results (results: for 1_PS - $t=1.528$ as $p=.131$; for PS $t=1.438$ as $p=.155$ ). By relying on the mathematical model for 1_PS, additional validation of the empirical підтверджує реалізацію в задачі ПДВ закону У. Хіка як в серіях 3 та 4, так і в серії 5 (див. табл. 1 і 3).

У зв'язку з представленими результатами, відокремлюються два пов'язані аспекти розгляду організації сенсомоторних дій в задачі ПДВ. По-перше, це визначення згідно з математичною моделлю (див. табл. 2) найменшого необхідного часу для повноцінного переорієнтування суб'єкта на апперцептивну схему реагування у варіанті 1_MC і встановлення його відповідності емпіричному результату. По-друге, це встановлення ідентичності структури сенсомоторного реагування на різні варіанти завдань у випадку зі змінним та фіксованим значеннями часу орієнтування.

Емпірично встановлено мінімально необхідний час орієнтування для повноцінної реалізації варіанту 1_MC в серії 5 ( $\bar{M}=.195$ c; $S D=.062$ c). 3 використанням математичної моделі для варіанту 1_MC було розраховано необхідний час орієнтування з підстановкою у формулу медіани часу простої реакції в серії 1 (див. табл. 3). Було отримано значення, що дорівнює .208 с. Цей розрахований необхідний час переорієнтування виявився таким, що статистично невиразно відрізняється від наведеного вище емпіричного визначення мінімально необхідного часу орієнтування (одновибірковий критерій: $t=1.762 ; p=.083)$. Тобто використане в серії значення критерію достатньо співпадає в теоретичній моделі й у практичній реалізації серії 5, коли в якості критерію програмної зміни часу орієнтування саме і задається час простої сенсомоторної реакції з серії 1. До того ж значення часу реагування для варіанту 1_MC в серії 5 не відрізняється суттєво від критеріального значення медіани простої сенсомоторної реакції в серії 1 (одновибірковий критерій: $t=1.354$; $p=.181$ ).

Визначалася ідентичність організації процесів реагування у варіантах задачі ПДВ з фіксованими значеннями часу орієнтування (серії 3 та 4) та зі змінним значенням часу орієнтування (серія 5). Для цього розраховувалися на основі математичних моделей (див. табл. 2) теоретичні визначення необхідного часу орієнтування і відповідного часу сенсомоторної дії для варіантів 1_MC та 3_MC, які

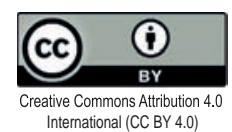


adequacy of theoretically determined psychological mechanisms for solving the DC task was carried out through determining the required orientation time of the subject upon the empirically obtained response time to 1_PS in series $5(.201 \mathrm{sec})$. The calculated result is also not statistically different from the empirically established orientation time in series $5(t=.845 ; p=.401)$.

The complex analysis of the results shows that the absolute values of the sensorimotor response time decline upon a significant amount of orientation time in series 3 and 4 compared to the time of simple reaction. Statistical comparison of these indicators also confirmed the availability of anticipatory effect upon the values of orientation time equal to $.25 \mathrm{sec}$ and $.30 \mathrm{sec}$ (respectively: $t=$ 3.138 as $p=.003 ; t=8.656$ as $p<.001$ ).

\section{Discussion}

The experiment outcome proved the availability of the subject's initial attitude towards the processing of the largest segment of the expected information in an uncertain environment (Konopkyn, 1980). From the outset, the study participants were obligatory oriented to the 3_PS option when addressing the DC task. The obtained empirical data also indicate a firm difference in the effectiveness of the participants' reactions in 1_PS and 3_PS upon extending a period of the orientation time (see table 1). This difference becomes significant in the case of orientation time of $.05 \mathrm{sec}$. The linear decrease in the orientation time reaches the values that are less than the time of a simple reaction in series 1 (see tables 1 and 3). As a result, an anticipatory component is clearly distinguished in the apperception scheme of sensorimotor reaction in 1_PS. Moreover, the anticipatory effect is clearly manifested only when the duration of the previous orientation turns to be sufficient for the full implementation of a simple sensorimotor response.

The anticipatory component of the apperceptive scheme for 1_PS is sufficiently actualized due to the consideration of activity of the time period from the cue to the appearance of the stimulus itself in the mechanisms of mental self-regulation attheunconsciouslevel.Inseries5, thecurrentstudy provided for program variations of the orientation time proposed to the study participants taking into потім зіставлялися (одновибірковий $t$-критерій) з відповідними емпіричними даними по серії 5. Було зроблено декілька розрахунків. Для підтвердження відповідності математичних моделей залежності часу сенсомоторного реагування від часу орієнтування для серії 5 у варіантах 1_MC та 3_MC були розраховані теоретичні значення часу сенсомоторного реагування при підстановці емпіричного значення необхідного часу орієнтування в серії 5 (розраховано: для 1_MC - .230 с; для 3_MC .299 с). Вирахувані теоретичні значення статистично порівнювалися 3 емпіричними результатами в серії 5. Суттєвих статистичних розбіжностей в теоретичних та емпіричних результатах не було встановлено (результат: для 1_МC $-t=1.528$ при $p=.131$; для 3_MC $t=1.438$ при $p=.155$ ). Додаткова перевірка емпіричної адекватності теоретично визначених психологічних механізмів розв'язання задачі ПДВ здійснювалася через визначення за допомогою математичної моделі для варіанту 1_MC необхідного часу орієнтування досліджуваного при емпірично отриманому часі реагування на варіант 1_MC в серії $5(.201$ c). Такий розрахований результат статистично також не відрізняється від емпірично встановленого часу орієнтування в серії 5 ( $t=.845 ; p=.401)$.

3 комплексного аналізу результатів табл. 1 і табл. 3 видно, що абсолютні значення часу сенсомоторного реагування при значному часі орієнтування в серіях 3 і 4 стають менше, порівняно з часом простої реакції. Статистичне порівняння цих показників також підтвердило наявність антиципаційного ефекту при значеннях часу орієнтування в .25 с та .30 с (відповідно: $t=3.138$ при $p=.003$; $t=8.656$ при $p<.001)$.

\section{Дискусія}

Результатами експерименту підтверджено наявність у суб'єкта в умовах невизначеності початкового налаштування на опрацьовування найбільшого сегменту очікуваної інформації (Конопкин, 1980). Досліджуванні при вирішенні задачі ПДВ з початку обов'язковим чином були зорієнтовані на варіант 3_MC. Отримані емпіричні дані також вказують і на неухильне розходження результативності 
account its minimum required value (a criterion). Such variations somewhat affect the subject's previous attitude towards the next reaction. However, empirically determined response time in the 1_PS option in series 5 does not significantly differ from the criterion value (of a median of a simple sensorimotor response in series 1) or the response time calculated from a mathematical model. It should be noted that under these conditions, the anticipatory component is not yet fully activated. On the other hand, the reaction time could increase without a positive contribution of actions derived from this component to the system of mental self-regulation. At the same time, the grade angle of the calculated linear dependence of the reaction time on the orientation time for the 1_PS option would also change and approach the grade of linear dependence for the 3_PS option (see table 2).

There is also an increase, albeit slow, in response rate upon increasing orientation time for 3_PS in series 3, 4 and 5. However, in this case, the study participants' consideration of the orientation time deals with the need for a delay to make the next choice of the proposed on-screen positions of the expected stimulus. Despite of the latter, the response efficiency of the study participants in the DC task in 3_PS is higher compared to the sensorimotor choice response in series 2 (see tables 1 and 3 ).

It is worth mentioning that the steady increase of the value of the anticipatory component in the apperception scheme of sensorimotor response expressly contributes to the intensification of the functioning of the psychological system of self-regulation of activity (Cheban et al., 2020a; Konopkyn, 1980). This effect indicates the participants' active search for resources to perform actions at different levels of mental regulation. It is this orientation that can characterize the readiness of the subject to urgent changes in the course of actions and the actions themselves in specific and extreme conditions (Cheban et al., 2020c; Plokhikh, 2019; Shumylov, 2006).

The empirical results do not significantly differ for both proposed variants of the DC problem. These results also don't differ from the expected ones. Hick's Law is fully realized both in the case of flexible automatic changes in the orientation реакцій досліджуваних у варіантах 1_MC та 3_MC при збільшенні часу орієнтування (див. табл. 1). Таке розходження стає суттєвим вже у разі часу орієнтування в .05 с. Лінійне зменшення часу орієнтування проходить до значень, які $\epsilon$ меншими від часу простої реакції у серії 1 (див. табл. 1 і 3). Через це чітко виокремлюється антиципаційна складова в апперцептивній схемі сенсомоторної реакції у варіанті 1_МС. Разом із цим антиципаційний ефект вочевидь проявляється тільки тоді, коли тривалість попереднього орієнтування стає достатньою для повноцінної реалізації простої сенсомоторної реакції.

Антиципаційна складова апперцептивної схеми для 1_МС достатньою мірою актуалізується внаслідок урахування в механізмах психічної саморегуляції на неусвідомлюваному рівні активності проміжку часу від попереджувального сигналу і до появи самого стимулу. I в нашому дослідженні в серії 5 було передбачено програмні варіації пропонованого досліджуваним часу орієнтації саме з урахуванням його найменшого необхідного значення (критерію). Такі варіації дещо знижують попереднє налаштування суб'єкта на наступну реакцію. Однак емпірично отриманий час реагування у варіанті 1_MC в серії 5 суттєво не відрізняється не від значення критерію (медіани простої сенсомоторної реакції в серії 1), не від розрахованого за математичною моделлю часу реагування. Слід вважати, що в цих умовах антиципаційний компонент ще не активовано у повній мірі. Але, з іншого боку, без позитивного внеску в систему психічної саморегуляції дій від цього компоненту час реакції міг би збільшитися. Разом із цим змінився б і кут нахилу розрахованої лінійної залежності часу реакції від часу орієнтування для варіанту 1_MC і наблизився б до куту лінійної залежності для варіанту 3_MC (див. табл. 2).

Для варіанту 3_MC в серіях 3, 4 та 5 також спостерігається, хоча й повільне, але підвищення швидкості реагування при збільшенні часу орієнтування. Однак у цьому випадку врахування досліджуваними часу орієнтування стикається 3 необхідністю затримки для наступного вибору з пропонованих на екрані позицій очікуваного стимулу. Але 
time, taking into account the criterion of the desired response speed, and in the case of a direct set of the orientation time from the list (Chuprykova, 1995). In the context of specific time values, the latter provides a comprehensive distinction between the implementation of apperception schemes of sensorimotor response in 1_PS and 3_PS. Thus, the use of the DC task allows one to sufficiently determine the orientation time required by the subject to transform the course of actions in response to significant changes in the current situation. It stands to reason the sooner the necessary reorientation of the subject to new circumstances happens, he is more likely to succeed in business.

\section{Conclusions}

1. In the context of the need for urgent actions in response to sharp changes in the current situation, mental image managing actions should be reoriented to a new situation as soon as possible. A double choice task, which provides for the following, can be a model variant of the reorientation: first, there is a choice of sensorimotor response (simple sensorimotor response or sensorimotor response of choice among three alternatives) in terms of the orientation cues; second, when a stimulus is displayed from an updated set of alternatives, the subject's motor response occurs. In terms of sensorimotor tasks, controlling image is simplified to the apperception scheme that defines a mode of actions.

2. Under the framework of the construction of the operation image and mode of actions of the subject in the double choice task, urgent fullfledged transition from the initial apperception scheme of sensorimotor response of choice among three alternatives to the apperception scheme of simple sensorimotor response requires some time - orientation time. The linear dependence of the time of a simple sensorimotor reaction on the orientation time is experimentally proved towards the "double choice" task.

3. The encompassing of the operation image of the anticipatory component, which essentially improves the subject's effectiveness, by the apperception scheme is the effect of using a cue for the actual variant of sensorimotor response навіть, не зважаючи на останнє, ефективність реагування досліджуваних в задачі ПДВ у варіанті 3_МС вище, порівняно з сенсомоторною реакцією вибору в серії 2 (див. табл. 1 і 3).

Слід вказати, що неухильне збільшення ваги антиципаційного компоненту в апперцептивній схемі сенсомоторного реагування однозначно сприяє інтенсифікації функціонування психологічної системи саморегуляції діяльності (Cheban et al., 2020a; Конопкин, 1980). Цей ефект свідчить про активний пошук досліджуваними на різних рівнях психічної регуляції ресурсів для виконання дій. Саме такою спрямованістю і можна охарактеризувати готовність суб'єкта до термінових змін образу дій і самих дій в особливих та екстремальних умовах (Cheban et al., 2020с; Плохих, 2019; Шумилов, 2006).

Для обох запропонованих варіантів задачі ПДВ емпіричні результати суттєво не відрізняються. Не відрізняються ці результати й від передбачуваних. I у разі гнучких автоматичних змін часу орієнтування з урахуванням критерію бажаної швидкості реагування, i у випадку прямого завдання часу орієнтування з переліку можливих, в повній мірі реалізується закон У. Хіка (Чуприкова, 1995). Останнє за певних значень часу орієнтування забезпечує вичерпне розрізнення реалізацій апперцептивних схем сенсомоторного реагування у варіантах 1_MC та 3_MC. Таким чином, використання задачі ПДВ дозволяє у достатній мірі визначати час орієнтування, необхідний суб'єкту для повноцінної зміни образу дій у відповідь на значущі зміни поточної ситуації. I, звичайно, чим швидше відбувається необхідна переорієнтація суб'єкта на нові обставини, тим більше у нього шансів на досягнення успіху в діяльності.

\section{Висновки}

1. В умовах необхідності термінових дій у відповідь на різкі зміни поточної ситуації керуючий діями психічний образ повинен бути якомога швидше переорієнтований на нову ситуацію. Модельним варіантом такої переорієнтації може бути задача "подвійного вибору", в якій передбачається наступне: по-перше, по запропонованим орієнтирам

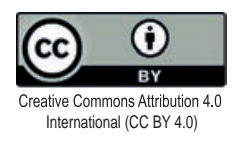


(simple sensorimotor response or sensorimotor choice response) in the double choice problem.

4. The method of constructing the double choice task with automatic variations of orientation time in the inclination of the subject to meet a given criterion - the time of a simple sensorimotor reaction - is identical to the method of direct setting of orientation time from many alternatives. In keeping with the specified criterion for the time of sensorimotor reaction, automatic variations of orientation time allow fixing the time necessary for urgent development of a new operation image and a way of actions.

\section{References}

Cheban, Yo. V., Chebykin, O. Ya., Plokhikh, V. V., \& Massanov A.V. (2020a). Emotional and volitional potential of self-mobilization in the organization of time perspective activity of highly qualified rowing athletes. Journal of Physical Education and Sport, Vol 20 (Supplement issue 6), 31283137. DOI: $10.7752 /$ jpes.2020.s6424

Cheban, Yu. V., Chebykin, O. Ya., Plokhikh, V. V. \& Massanov A.V. (2020b). Emotional factor of competitive self-mobilization of professional rowers. Insight: the psychological dimensions of society, 3, 28-43. DOI: $10.32999 / 2663-970 X / 2020-3-2$

Cheban, Yu., Chebykin, O., Plokhikh, V. \& Massanov, A. (2020c). Mental resources for the self-mobilization of rowing athletes. Journal of Physical Education and Sport, Vol.20 (3), 1580-1589. DOI:10.7752/ jpes.2020.03216

Chkhartishvili, Sh. N. (1978). On the question of the ontological nature of the unconscious. The unconscious: Nature, function research methods. In F. V. Bassina, A. S. Prangishvili \& A. E. Sherozia (Eds.). Tbilisi.

Chuprikova, N. I. (1995). Reaction time and intelligence: why are they related (about discriminative ability of the brain). Psychology issues. 4, 65-81.

Konopkin, O. A. (1980). Psychological mechanisms of activity regulation. Moscow: Science.

Lynall, R. C., Blackburn, J. T., Guskiewicz, K. M., Marshall, S. W., Plummer, P. \& Mihalik J. P. (2018). Reaction time and joint kinematics during functional movement in recently concussed individuals. Arch. Phys. Med. Rehabil. 99, 880-886. DOI: 10.1016/j.apmr.2017.12.011

Nosov, P., Popovych, I., Zinchenko, S., Cherniavskyi, V., Plokhikh, V., \& Nosova, H. (2020). The research on anticipation of vessel captains by the space of Kelly's graph. Revista Inclusiones, Vol: 7 num Especial, 90-103.

Okubo, Y., Schoene, D., \& Okubo, Y. (2017). Step training improves reaction time, gait and balance відбувається вибір варіанту сенсомоторного реагування (проста сенсомоторна реакція або сенсомоторна реакція вибору з трьох альтернатив); по-друге, при пред'явленні стимулу 3 актуалізованого набору альтернатив відбувається рухова відповідь суб’єкта. У завданнях сенсомоторного реагування керуючий образ спрощується до апперцептивної схеми, що визначає спосіб дії.

2. У межах побудови оперативного образу і способу дій суб'єкта в задачі “подвійного вибору” терміновий повноцінний перехід 3 початкової апперцептивної схеми сенсомоторної реакції вибору з трьох альтернатив на апперцептивну схему простої сенсомоторної реакції вимагає певного часу - часу орієнтування. Для задачі “подвійного вибору” експериментально доведено лінійну залежність часу простої сенсомоторної реакції від часу орієнтування.

3. Ефектом від використання попереджувального сигналу про актуальний варіант сенсомоторного реагування (проста сенсомоторна реакція або сенсомоторна реакція вибору) в задачі “подвійного вибору" $\epsilon$ включення до апперцептивної схеми оперативного образу антиципаційного компоненту, який суттєво підвищую ефективність дій суб'єкта.

4. Спосіб побудови задачі “подвійного вибору" з автоматичними варіаціями часу орієнтування в налаштуванні суб'єкта на дотримання заданого критерію - часу простої сенсомоторної реакції, ідентичний до способу прямого завдання часу орієнтування з безлічі можливих. Автоматичні варіації часу орієнтування при дотриманні заданого критерію щодо часу сенсомоторної реакції дозволяють визначити необхідний час для термінового формування нового оперативного образу і способу дій.

\section{Список використаних джерел}

Cheban, Yu. V., Chebykin, O. Ya., Plokhikh, V. V. \& Massanov A. V. (2020a). Emotional and volitional potential of self-mobilization in the organization of time perspective activity of highly qualified rowing athletes. Journal of Physical Education and Sport, Vol 20 (Supplement issue 6), P. 3128 - 3137. DOI:10.7752/jpes.2020.s6424

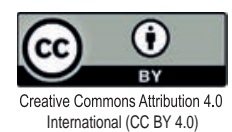


and reduces falls in older people: a systematic review and meta-analysis. Br. J. Sports Med., 51, 586-593. DOI: 10.1136/bjsports-2015-095452

Plokhikh, V. V. (2019). Anticipatory processes in the organization of timely human actions. Actual problems of psychology: Collection of Science Papers of G. S. Kostiuk Institute of Psychology NAPS of Ukraine. Psychology of creativity, 26 (XII), 250-262.

Popovych, I. S., Blynova, O. Ye., Bokshan, H. I., Nosov, P. S., Kovalchuk, Z. Ya., Piletska, L. S., \& Berbentsev, V. I. (2019). The Research of the Mental States of Expecting a Victory in Men Mini-football Teams. Journal of Physical Education and Sport, 19(4), 2343-2351. DOI:10.7752/jpes.2019.04355

Popovych, I., Zavatskyi, V., Tsiuniak, O., Nosov, P., Zinchenko, S., Mateichuk, V., Zavatskyi, Yu. \& Blynova, 0. (2020). Research on the types of pregame expectations in the athletes of sports games. Journal of Physical Education and Sport, 20(1), 43-52. DOI:10.7752/jpes.2020.01006

Reigal, R.E., Barrero, S., Martín, I., Morales-Sánchez, V., Juárez-Ruiz, de Mier, R. and Hernández-Mendo, A. (2019). Relationships Between Reaction Time, Selective Attention, Physical Activity, and Physical Fitness in Children. Front. Psychol. https://doi. org/10.3389/fpsyg.2019.02278

Sant'Ana, J., Franchini, E., da Silva, V., and Diefenthaeler, F. (2016). Effect of fatigue on reaction time, response time, performance time, and kick impact in taekwondo roundhouse kick. Sport Biomech, 16, 201-209. doi: 10.1080/14763141.2016.1217347

Shumilov, I.S. (2006). Aviation accidents. Causes of occurrence and possibilities of prevention. Moscow: Publishing house of the Bauman Moscow State Technical University.

Silverman, I.W. (2010). Simple reaction time: It is not what it used to be. The American Journal of Psychology. V. 123. № 1. P. 39-50.

Van de Water, T., Huijgen, B., Faber, I., and Elferink-Gemser, M. (2017). Assessing cognitive performance in badminton players: a reproducibility and validity study. J. Hum. Kinet. 55, 149-159. doi: 10.1515/ hukin-2017-0014

Zavalova, N. D., Lomov, B. F. \& Ponomarenko, V. A. (1986). Image in the system of mental regulation of activity. Moscow: Science.
Cheban, Yu. V., Chebykin, O. Ya., Plokhikh, V. V. \& Massanov A.V. (2020b). Emotional factor of competitive self-mobilization of professional rowers. Insight: the psychological dimensions of society, №.3, P. 28-43. DOI: 10.32999/2663-970X/2020-3-2

Cheban, Yu., Chebykin, O., Plokhikh, V. \& Massanov, A. (2020c). Mental resources for the self-mobilization of rowing athletes. Journal of Physical Education and Sport, Vol. 20 (3), P. 1580-1589. DOI:10.7752/ jpes.2020.03216

Чхартишвили, Ш. Н. (1978) К вопросу об онтологической природе бессознательного. Бессознательное (The unconscious): Природа, функции методы исследования / Под ред. Ф. В. Бассина, А.С. Прангишвили, A.Е. Шерозия. Тбилиси, С. 95-110.

Чуприкова Н.И., (1995). Время реакций и интеллект: почему они связаны (о дискриминативной способности мозга). Вопросы психологии. №4. C. $65-81$.

Конопкин, О.А. (1980). Психологические механизмы регуляции деятельности. М.: Наука. 256 с.

Lynall, R. C., Blackburn, J. T., Guskiewicz, K. M., Marshall, S. W., Plummer, P., and Mihalik, J. P. (2018). Reaction time and joint kinematics during functional movement in recently concussed individuals. Arch. Phys. Med. Rehabil. №99, P. 880-886. doi: 10.1016/j.apmr.2017.12.011

Nosov, P., Popovych, I., Zinchenko, S., Cherniavskyi, V., Plokhikh, V. \& Nosova, H. (2020). The research on anticipation of vessel captains by the space of Kelly's graph. Revista Inclusiones, Vol: 7 num Especial, P. 90-103.

Okubo, Y., Schoene, D., and Lord, S. R. (2017). Step training improves reaction time, gait and balance and reduces falls in older people: a systematic review and meta-analysis. Br. J. Sports Med. № 51, P. 586-593. DOI: 10.1136/ bjsports-2015-095452

Плохих, В. В. (2019). Антиципационные процессы в организации своевременных действий человека. Актуальні проблеми психологї: Збірник наукових праць Інституту психології імені Г.С. Костюка НАПН України. Психологія творчості. К: “Фенікс”. №26 (XII). С. 250-262.

Popovych, I., Zavatskyi, V., Tsiuniak, O., Nosov, P., Zinchenko, S., Mateichuk, V., Zavatskyi, Yu. \& Blynova, O. (2020). Research on the types of pregame expectations in the athletes of sports games. Journal of Physical Education and Sport, № 20(1), P. 43-52. DOI:10.7752/jpes.2020.01006

Popovych, I. S., Blynova, O. Ye., Bokshan, H. I., Nosov, P. S., Kovalchuk, Z. Ya., Piletska, L. S., \& Berbentsev, V. I. (2019a). The Research of the Mental States of Expecting a Victory in Men Mini-football Teams. Journal of Physical Education

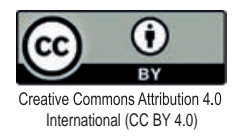


and Sport, № 19(4), P. 2343-2351. DOI:10.7752/ jpes.2019.04355

Reigal, R.E., Barrero, S., Martín, I., Morales-Sánchez, V., Juárez-Ruiz, de Mier, R. and Hernández-Mendo, A. (2019). Relationships Between Reaction Time, Selective Attention, Physical Activity, and Physical Fitness in Children. Front. Psychol. https://doi. org/10.3389/fpsyg.2019.02278

Sant'Ana, J., Franchini, E., da Silva, V., and Diefenthaeler, F. (2016). Effect of fatigue on reaction time, response time, performance time, and kick impact in taekwondo roundhouse kick. Sport Biomech. № 16, P. 201-209. doi: 10.1080/14763141.2016.1217347

Шумилов, И.С. (2006). Авиационные происшествия. Причины возникновения и возможности предотвращения. М.: Изд-во МГТУ имени Н. Э. Баумана. 384 с.

Silverman I.W. (2010). Simple reaction time: It is not what it used to be. The American Journal of Psychology. V. 123. № 1. P. 39-50.

Van de Water, T., Huijgen, B., Faber, I., and Elferink-Gemser, M. (2017). Assessing cognitive performance in badminton players: a reproducibility and validity study. J. Hum. Kinet. № 55, P. 149-159. doi: 10.1515/hukin-2017-0014

Завалова, Н. Д., Ломов, Б. Ф., Пономаренко, В. А. (1986). Образ в системе психической регуляции деятельности. М.: Наука. 175 с. 